\title{
The Role of Hydrogen Sulphide in Blood Pressure Regulation
}

\author{
S. CACANYIOVA ${ }^{1}$, A. BERENYIOVA ${ }^{1}$, F. KRISTEK ${ }^{1}$ \\ ${ }^{1}$ Institute of Normal and Pathological Physiology, Slovak Academy of Sciences, Bratislava, Slovak \\ Republic
}

Received July 1, 2016

Accepted September 5, 2016

\section{Summary}

Cardiovascular studies have confirmed that hydrogen sulphide $\left(\mathrm{H}_{2} \mathrm{~S}\right)$ is involved in various signaling pathways in both physiological and pathological conditions, including hypertension. In contrast to nitric oxide (NO), which has a clear vasorelaxant action, $\mathrm{H}_{2} \mathrm{~S}$ has both vasorelaxing and vasoconstricting effects on the cardiovascular system. $\mathrm{H}_{2} \mathrm{~S}$ is an important antihypertensive agent, and the reduced production of $\mathrm{H}_{2} \mathrm{~S}$ and the alterations in its functions are involved in the initiation of spontaneous hypertension. Moreover, cross-talk between $\mathrm{H}_{2} \mathrm{~S}$ and NO has been reported. $\mathrm{NO}-\mathrm{H}_{2} \mathrm{~S}$ interactions include reactions between the molecules themselves, and each has been shown to regulate the endogenous production of the other. In addition, $\mathrm{NO}$ and $\mathrm{H}_{2} \mathrm{~S}$ can interact to form a nitrosothiol/s complex, which has original properties and represents a novel nitroso-sulphide signaling pathway. Furthermore, recent results have shown that the interaction between $\mathrm{H}_{2} \mathrm{~S}$ and $\mathrm{NO}$ could be involved in the endothelium-regulated compensatory mechanisms that are observed in juvenile spontaneously hypertensive rats. The present review is devoted to role of $\mathrm{H}_{2} \mathrm{~S}$ in vascular tone regulation. We primarily focus on the mechanisms of $\mathrm{H}_{2} \mathrm{~S}-\mathrm{NO}$ interactions and on the role of $\mathrm{H}_{2} \mathrm{~S}$ in blood pressure regulation in normotensive and spontaneously hypertensive rats.

\section{Key words}

Hydrogen sulphide $\bullet$ Nitric oxide $\bullet$ Vascular tone $\bullet$ Hypertension $\bullet$ Nitroso-sulphide

\section{Corresponding author}

S. Cacanyiova, Institute of Normal and Pathological Physiology, Slovak Academy of Sciences, Sienkiewiczova 1, 81371 Bratislava, Slovak Republic. E-mail: sona.cacanyiova@savba.sk

\section{Introduction}

Hydrogen sulphide $\left(\mathrm{H}_{2} \mathrm{~S}\right)$ is a simple gaseous molecule that participates as a transmitter in the regulation of vascular reactivity. Until the last two decades of the 20th century, all known chemical transmitters were liquids. Furchgott and Zawadzki (1980) demonstrated that the relaxation of rabbit aorta following acetylcholine administration is dependent on the endothelium, and the substance responsible for the vascular relaxation was determined to be an endotheliumderived relaxing factor. Palmer et al. (1987) proved that this substance is pharmacologically identical to nitric oxide (NO). NO was then determined to be one of the most important signaling molecules in biological control systems. Moreover, NO was the first gaseous molecule that fulfilled the criteria of a transmitter. Specifically, gaseous transmitters must be 1) freely membrane permeable; 2) endogenously and enzymatically generated and regulated; 3 ) have defined functions at physiological concentrations; and 4) have specific cellular and molecular targets, although second messengers are not needed (Wang 2002). Marks et al. (1991) discovered that another simple gaseous molecule, carbon monoxide (CO), operates as a transmitter in the mediation of vasoactivity. Abe and Kimura (1996), who studied neuronal activity, identified a third gaseous transmitter, namely, $\mathrm{H}_{2} \mathrm{~S}$. The vasoactivity of this compound was revealed by Hosoki et al. (1997).

The gaseous transmitters in the cardiovascular system differ in terms of their physiological concentrations. In arterial blood, the concentration of NO in physiological conditions is about $150 \mathrm{nmol} / \mathrm{l}$ (Gerová 
et al. 1996). This value was measured with a porphyrinic biosensor in the blood stream close to endothelial cells in the femoral artery of a normotensive dog. The nonpathological $\mathrm{CO}$ production of the human body is $20 \mu \mathrm{mol} / \mathrm{h}$ (Durante et al. 2006). Data on the concentration of $\mathrm{H}_{2} \mathrm{~S}$ in the cardiovascular system varies between $10 \mathrm{nmol} / \mathrm{l}$ and $300 \mu \mathrm{mol} / \mathrm{l}$ (discussed in more detail below). Unfortunately, the published data on the concentration of gaseous transmitters often depend on the methods used.

As all three gaseous transmitters have vasoactive effects, it is likely that they participate in blood pressure regulation. The vascular tone is determined by the interactions between various neurohumoral factors and mechanical forces in cooperation with vasorelaxant and vasoconstrictor substances released by the vascular wall. In physiological conditions, the final effect of these factors is shifted towards vasorelaxation. In pathological conditions, e.g. hypertension, the balance is disturbed due to enhanced vasoconstricting effects and increased vascular tone. $\mathrm{H}_{2} \mathrm{~S}$, in contrast to $\mathrm{NO}$, which has a clear vasorelaxant action, has both vasorelaxing and vasoconstricting effects on the arterial system. It is difficult to study the contribution of $\mathrm{H}_{2} \mathrm{~S}$ to the regulation of vascular tone in physiological and/or pathological conditions, and these effects have been unsatisfactorily explored in the literature. NO and CO act via binding to the heme moiety at the active site of guanylate cyclase. $\mathrm{H}_{2} \mathrm{~S}$ acts in part by opening ATP-sensitive potassium channels $\left(\mathrm{K}_{\mathrm{ATP}}\right)$ on the vascular smooth muscle cells (Zhao et al. 2001, Zhao and Wang 2002, Drobna et al. 2015) and in part by stimulating endothelium-derived NO production (Zhao and Wang 2002). Although gaseous transmitters operate in distinct ways, studies have revealed that they can act cooperatively. In the present review, we focus our attention primarily on the physiological effects of $\mathrm{H}_{2} \mathrm{~S}$ in the cardiovascular system.

\section{Biochemical properties, biosynthesis and breakdown of $\mathrm{H}_{2} \mathrm{~S}$}

The synthesis of $\mathrm{H}_{2} \mathrm{~S}$, similarly to $\mathrm{NO}$ and $\mathrm{CO}$, occurs endogenously by means of various enzymes, and this compound has been proven to be involved in many pathological processes, including vascular relaxation, hypertension, cellular proliferation, gene expression, cardioprotection, neuroprotection, intestinal secretion, diabetes, apoptosis, atherosclerosis and inflammation. The molecular background of the effects of $\mathrm{H}_{2} \mathrm{~S}$ and its signaling at the cellular level are currently unknown. However, it is possible that one of the key mechanisms could be a modification of cysteine $\mathrm{SH}$ groups to $\mathrm{SSH}$ groups during the generation of S-sulph-hydrated proteins. S-sulph-hydration, evoked by endogenously produced $\mathrm{H}_{2} \mathrm{~S}$, can occur on various proteins and modifies their physiological properties. This posttranslational modification is similar to S-nitrosylation, which is induced by NO, and could be an important signaling mechanism with various effects on the cardiovascular system.

$\mathrm{H}_{2} \mathrm{~S}$ dissolved in water is a weak acid and dissociates into $\mathrm{H}^{+}, \mathrm{HS}^{-}$, and $\mathrm{S}^{2-}$. At physiological $\mathrm{pH}$ (7.4), such as in the blood and other physiological solutions, approximately $14 \%$ of the free sulphides are present as gaseous $\mathrm{H}_{2} \mathrm{~S}$, more than $80 \%$ is present as $\mathrm{HS}^{-}$, and the rest is $\mathrm{S}^{2-}$. It is still undetermined which form is biologically active. An important property of gaseous $\mathrm{H}_{2} \mathrm{~S}$ is its lipophilicity. Similarly to $\mathrm{O}_{2}$ and $\mathrm{CO}_{2}, \mathrm{H}_{2} \mathrm{~S}$ easily penetrates the cell membrane (Wang et al. 2012). Due to its vaporous quality, $\mathrm{H}_{2} \mathrm{~S}$ easily leaves the blood into the lung and/or from the incubating medium to the air (Liu et al. 2012). Some studies state that the concentration of free $\mathrm{H}_{2} \mathrm{~S}$ in blood and tissues is only 14-15 nmol/1 (Doeller et al. 2005, Furne et al. 2008). The concentration of free sulphides in the blood and other tissues/physiological solutions of mammals is very low $(<100 \mathrm{nmol} / \mathrm{l})$, but it can be increased in the parts of the body where increased concentrations of $\mathrm{H}_{2} \mathrm{~S}$ synthesizing enzymes are present (Whitfield et al. 2008). In specific intracellular spaces (microspaces), the concentration of free $\mathrm{H}_{2} \mathrm{~S}$ can be increased several fold, whereupon it immediately diffuses, binds or oxidizes. For example, a much higher concentration of $\mathrm{H}_{2} \mathrm{~S} \quad(1 \mu \mathrm{mol} / \mathrm{l})$ is observed in the aorta of mice. This concentration is 20-200 times higher in comparison with other tissues (Levitt et al. 2011). It is suggested that endogenously produced $\mathrm{H}_{2} \mathrm{~S}$ is rapidly oxidized to sulphates or incorporated into proteins. In this form, free $\mathrm{H}_{2} \mathrm{~S}$ can be released after some physiological stimuli and temporally achieve increased concentrations (Ishigami et al. 2009). Under the in vitro conditions (e.g. organ bath, cell culture), a concentration of $\mathrm{H}_{2} \mathrm{~S}$ lower than $100 \mu \mathrm{mol} / 1$ is proposed to be physiologically relevant. The in vivo experiments indicate that the mode of $\mathrm{H}_{2} \mathrm{~S}$ application (i.e. intravenous, intraperitoneal, hypodermic) is important given that this choice can modulate $\mathrm{H}_{2} \mathrm{~S}$ bioavailability. In the context of oral administration, a high percentage of $\mathrm{H}_{2} \mathrm{~S}$ is metabolized in the 
gastrointestinal tract and the liver before it reaches the target organ.

Both free and bounded sulphides are produced by the enzymes that synthesized $\mathrm{H}_{2} \mathrm{~S}$. Three enzymes can convert the amino acid L-cysteine to $\mathrm{H}_{2} \mathrm{~S}$ : cystathionine $\beta$-synthase (CBS), cystathionine $\gamma$-lyase (CSE) and cysteine-aminotransferase (CAT) in conjunction with mercaptopyruvate-sulphurtransferase (3-MST). The gene expression of CBS and CSE has been detected in various cell types, including the liver, kidney, lymphatic system, vascular wall, cardiomyocytes, and fibroblasts. While these enzymes contribute equally to the local production of $\mathrm{H}_{2} \mathrm{~S}$ in the liver and kidney (Xia et al. 2009), one of the enzymes could be dominant in other contexts. There is a prevalence of CSE in cardiovascular system, although CSE expression is $24 \%$ higher in the myocardium in comparison to the thoracic aorta (Geng et al. 2004). Relatively high concentration of CSE is observed in arteries, and $\mathrm{H}_{2} \mathrm{~S}$ is produced by both endothelial cells (Yang et al. 2008) and smooth muscle cells of the vessel wall (Zhao et al. 2001). The expression of CAT and 3-MST was also observed in the endothelium (Shibuya et al. 2009). The key enzyme for $\mathrm{H}_{2} \mathrm{~S}$ synthesis in the central and peripheral nervous system is CBS (Abe and Kimura 1996). The source of $\mathrm{H}_{2} \mathrm{~S}$ in brain could also be the CAT/3-MST complex (Ram 1988).

The sources of $\mathrm{H}_{2} \mathrm{~S}$ are the amino acids cysteine and methionine, which are present in food. Nearly all synthesized $\mathrm{H}_{2} \mathrm{~S}$ is immediately oxidized and incorporated into the structure of other liver proteins before entering into hepatic veins and the vena cava inferior (Furne et al. 2008). Most endogenously synthesized $\mathrm{H}_{2} \mathrm{~S}$ is oxidized to sulphates, which are then excreted by the kidney. Although every cell is able to oxidize $\mathrm{H}_{2} \mathrm{~S}$, it is primary degraded in liver (Furne et al. 2001, 2008). Mitochondria are very active in sulphide oxidation. $\mathrm{H}_{2} \mathrm{~S}$ molecules are oxidized to thiosulphate, which is ultimately converted to sulphide and sulphate by sulphate oxidase (Furne et al. 2008). Sulphates are then excreted in the urine in the free or conjugated form. $\mathrm{H}_{2} \mathrm{~S}$ is also trapped by hemoglobin or by molecules with metal or disulphide groups (e.g. oxidized glutathione). Hemoglobin generally decreases the level of all three gaseous transmitters $\left(\mathrm{CO}, \mathrm{NO}\right.$, and $\left.\mathrm{H}_{2} \mathrm{~S}\right)$. Due to their strong affinity to oxygen, this binding can mediate a great deal of the toxic effects of these molecules. The lung also participates in $\mathrm{H}_{2} \mathrm{~S}$ excretion in the case of increased $\mathrm{H}_{2} \mathrm{~S}$ production, e.g. during hemorrhagic conditions, septic shock or pancreatitis. In normal conditions, the amount of
$\mathrm{H}_{2} \mathrm{~S}$ excreted by expiration is negligible (Liu et al. 2012).

\section{Vasoactive effects of $\mathrm{H}_{2} \mathrm{~S}$}

The level of $\mathrm{H}_{2} \mathrm{~S}$ in the body depends on the presence of pathological conditions, including hypertension (Chen et al. 2007). Nevertheless, it is still an open question whether the concentration of $\mathrm{H}_{2} \mathrm{~S}$ depends on pathological conditions or vice versa. In addition, the mechanisms of $\mathrm{H}_{2} \mathrm{~S}$ action are not fully elucidated. In general, $\mathrm{H}_{2} \mathrm{~S}$ has been shown to have dual effects on the tone of the vascular wall.

Perfusion of the mesenteric system with $1 \mathrm{mmol} / \mathrm{l}$ cysteine (precursor of $\mathrm{H}_{2} \mathrm{~S}$ ) resulted in an increase of endogenous $\mathrm{H}_{2} \mathrm{~S}$ production and a dilation of the mesenteric circulation (Cheng et al. 2004). Sodium hydrosulphide (NaHS) at concentrations over $100 \mu \mathrm{mol} / 1$ evoked the relaxation of precontracted isolated rat arteries (Ali et al. 2006, Hosoki et al. 1997, Zhao et al. 2001). On the other hand, some observations revealed an opposite effect of $\mathrm{H}_{2} \mathrm{~S}$ on smooth muscle cells of the arterial wall. The application of the same doses on isolated precontracted arterial segments evoked vasoconstriction (Lim et al. 2008, Liu and Bian 2010). The vasoactive response of vessels to $\mathrm{H}_{2} \mathrm{~S}$ differs in dependence on several factors, for example, the type of vessel (conduit arteries, resistance arteries) the presence of an endothelium, the substance used for precontraction, and the concentration of $\mathrm{H}_{2} \mathrm{~S}$ applied. Higher concentrations of $\mathrm{H}_{2} \mathrm{~S}$ (sodium disulphide (NaHS): 2.8 and $14 \mu \mathrm{mol} / \mathrm{kg} ; 0.1-1 \mathrm{mmol} / \mathrm{l}$ ) evoked decrease of blood pressure or vasorelaxation in some types of isolated vessels (Zhao et al. 2001, Zhao and Wang 2002). Lower concentrations of $\mathrm{H}_{2} \mathrm{~S}\left(\mathrm{Na}_{2} \mathrm{~S}: 3 \mu \mathrm{mol} / \mathrm{kg} ; 10-100 \mu \mathrm{mol} / \mathrm{l}\right)$ resulted in blood pressure increase and vasoconstriction of the same vessels (Kubo et al. 2007, Lim et al. 2008, Drobna et al. 2015).

Published data indicate numerous possible mechanisms of $\mathrm{H}_{2} \mathrm{~S}$-induced vasoconstriction. One possible mechanisms of $\mathrm{H}_{2} \mathrm{~S}$-induced vasoconstriction is decreased levels of cyclic adenosine monophosphate (cAMP) in smooth muscle cells. Li et al. (2015) showed on the rat cerebral artery that $\mathrm{H}_{2} \mathrm{~S}$ evoked a decrease of cAMP levels, an effect that was associated with the promotion of an interaction between actin and myosin. The $\mathrm{H}_{2} \mathrm{~S}$-mediated decrease in cAMP concentrations stimulated the activation of myosin light chain kinase, an enzyme that mediates the interaction between actin and myosin (Lim et al. 2008). Li et al. (2015) also proved that 
$\mathrm{H}_{2} \mathrm{~S}$ did not directly influence cAMP levels but significantly reduced forskolin-stimulated adenylyl cyclase activity in human brain vascular smooth muscle cells. This result demonstrated that $\mathrm{H}_{2} \mathrm{~S}$-induced vasoconstriction was due to the inhibition of the cAMP/adenylyl cyclase pathway. It was also shown that the administration of low concentrations of $\mathrm{H}_{2} \mathrm{~S}$ (5-100 $\mu \mathrm{mol} / \mathrm{l})$ inhibited forskolin-induced cAMP accumulation in aortic smooth muscle. Moreover, NaHS was observed to inhibit vasorelaxing effects via $\beta$-adrenergic vasodilators and to induce vasoconstricting effects via adenylate cyclase and cAMP inhibition (Coletta et al. 2012). Ping et al. (2015) found that prostanoids could be involved in NaHS-induced vasoconstriction because the vasoconstriction evoked by $\mathrm{H}_{2} \mathrm{~S}$ was markedly attenuated in the presence of a cyclooxygenase inhibitor (indomethacin, $10 \mu \mathrm{mol} / \mathrm{l}$ ). It was concluded by the same authors that the contractile effect of $\mathrm{H}_{2} \mathrm{~S}$ was mediated by an influx of extracellular $\mathrm{Ca}^{2+}$ because the effect was totally inhibited in a $\mathrm{Ca}^{2+}$ free solution and following incubation with the $\mathrm{Ca}^{2+}$ influx blocker nifedipine.

$\mathrm{H}_{2} \mathrm{~S}$-induced vascular smooth muscle relaxation is predominantly induced through the activation of potassium channels leading to membrane hyperpolarization. The participation of several additional signaling pathways and mechanisms was also confirmed, including changes in intracellular $\mathrm{pH}$ or ATP levels as well as endothelium-derived mechanisms (Liu et al. 2012).

Several types of potassium channels have been reported to be major molecular targets of vasorelaxant $\mathrm{H}_{2} \mathrm{~S}$ effects. $\mathrm{H}_{2} \mathrm{~S}$ was able to induce hyperpolarization by stimulating $\mathrm{K}_{\mathrm{ATP}}, \mathrm{K}_{\mathrm{V}}$ and $\mathrm{KCNQ}$ potassium channels in a tissue-dependent manner. Zhao et al. (2001) confirmed an important role of $\mathrm{K}_{\text {ATP }}$ channels in high-dose $\mathrm{H}_{2} \mathrm{~S}$-induced vasorelaxation in isolated rat aortas. The acute administration of glibenclamide $\left(\mathrm{K}_{\mathrm{ATP}}\right.$ channel inhibitor) significantly inhibited the relaxant effects of $\mathrm{H}_{2} \mathrm{~S}$. Consistent with the role of $\mathrm{K}_{\mathrm{ATP}}$ channels in mediating the effects of $\mathrm{H}_{2} \mathrm{~S}$, reduced endogenous synthesis of $\mathrm{H}_{2} \mathrm{~S}$ decreased $\mathrm{K}_{\mathrm{ATP}}$ channel activity. Moreover, exogenous $\mathrm{H}_{2} \mathrm{~S}$ administration activated $\mathrm{K}_{\text {ATP }}$ channels and hyperpolarized the membrane of vascular smooth muscle cells isolated from rat mesenteric arteries (Tang et al. 2005). However, Cheang et al. (2010) showed that $\mathrm{K}_{\mathrm{ATP}}$ channels were not involved in mediating effects of $\mathrm{H}_{2} \mathrm{~S}$ in rat coronary arteries. These authors suggested voltage-dependent potassium $\left(\mathrm{K}_{\mathrm{V}}\right)$ channels as possible mediators of NaHS-evoked vasorelaxation. This conclusion was reached because specific inhibition of $\mathrm{K}_{\mathrm{V}}$ channels with 4-aminopyridine reduced $\mathrm{H}_{2} \mathrm{~S}$-induced relaxation of deendothelized rat coronary arteries. Schleifenbaum et al. (2010) proposed $\mathrm{H}_{2} \mathrm{~S}$ as a vasorelaxing factor released from perivascular adipose tissue and acting via the stimulation of special $\mathrm{Kv}$ type channels - KNCQ channels. Additionally, small, intermediate, and large conductance calcium-dependent potassium channels $\left(\mathrm{SK}_{\mathrm{Ca}}, \mathrm{IK}_{\mathrm{Ca}}\right.$ and $\left.\mathrm{BK}_{\mathrm{Ca}}\right)$ have also been demonstrated as possible mediators of $\mathrm{H}_{2} \mathrm{~S}$ vasodilator effects in resistance vessels (Mustafa et al. 2011, Jackson-Weaver et al. 2013). An $\mathrm{H}_{2}$ S-evoked increase in cyclic guanosine monophosphate (cGMP) levels could also be involved in $\mathrm{H}_{2} \mathrm{~S}$-induced vasorelaxation of smooth muscle cells. Bucci et al. (2010) confirmed that $\mathrm{H}_{2} \mathrm{~S}$ results in vasorelaxation by non-selectively inhibiting endogenous phosphodiesterase (PDE). This effect would increase tissue levels of cyclic nucleotides, such as cGMP. Changes in the intracellular acid-base balance also influence the vasoactivity of vascular smooth muscle cells. Generally, acidification has a vasorelaxant effect, whereas the alkalinization of the intracellular environment causes vasoconstriction in most of the vascular bed. According to data published by Lee et al. (2007), $\mathrm{H}_{2} \mathrm{~S}$ could modify the $\mathrm{pH}$ equilibrium in cells by activating the $\mathrm{Cl}^{-} / \mathrm{HCO}_{3}{ }^{-}$exchanger and thereby induce acidification. This signaling pathway is also associated with the stimulation of $\mathrm{K}_{\mathrm{ATP}}$ channels and so is involved in cell membrane hyperpolarization and vasorelaxation. The above-mentioned mechanisms of $\mathrm{H}_{2} \mathrm{~S}$ that are involved in the regulation of vascular smooth muscle tone represent only a small portion of possible $\mathrm{H}_{2} \mathrm{~S}$ signaling pathways. Indeed, one of the most important mechanisms of $\mathrm{H}_{2} \mathrm{~S}$ is its involvement in the regulation of vessel wall activity by influencing $\mathrm{NO}$ synthesis and bioactivity.

\section{Interactions between the $\mathrm{NO}$ and $\mathrm{H}_{2} \mathrm{~S}$ signaling pathways}

$\mathrm{H}_{2} \mathrm{~S}$ is an important component of the NO signaling pathway. Cross-talk between $\mathrm{NO}$ and $\mathrm{H}_{2} \mathrm{~S}$ has been suggested but has not been fully characterized. $\mathrm{NO}-\mathrm{H}_{2} \mathrm{~S}$ interactions and their effects on vascular tone control are the subjects of extensive research, and it has been confirmed that these interactions occur at different levels, i.e. at the molecular level as well as in the context of their respective synthetic pathways. 
Contradictory results regarding the synergistic and antagonistic effects of these gases have been published in recent years. Hosoki et al. (1997) reported the synergistic effect between $\mathrm{NO}$ and $\mathrm{H}_{2} \mathrm{~S}$. Pretreatment with $30 \mu \mathrm{mol} / 1$ of the $\mathrm{H}_{2} \mathrm{~S}$ donor NaHS alone did not show any relaxation effect on the thoracic aorta but significantly enhanced (by several fold) smooth muscle relaxation induced by exogenous NO donors (sodium nitroprusside and 3-morpholinosydnonimine). NaHS also shifted the dose-response curve of both NO donors to much lower concentrations. The synergistic effect with $\mathrm{NO}$ on smooth muscles was specific for $\mathrm{H}_{2} \mathrm{~S}$ given that other thiols, including endogenous substances (e.g. cysteine and glutathione), did not induce any relaxation effect alone or in synergy with NO. Coletta et al. (2012) also showed that $\mathrm{NO}$ and $\mathrm{H}_{2} \mathrm{~S}$ are mutually required for the physiological control of vascular function. The authors confirmed that pretreatment with a low concentration of NaHS ( $30 \mu \mathrm{mol} / \mathrm{l}, 15 \mathrm{~min})$ potentiated the vasorelaxant response of the thoracic aorta to acetylcholine and to $\mathrm{NO}$ donor diethylammonium salt (2-(N,N-diethylamino)-diazenolate-2-oxide, DEA/NO). Moreover, this pretreatment significantly increased cGMP levels in response to DEA/NO. In addition, CSE silencing resulted in a significant inhibition of the vasodilator responses of vascular rings to both vasodilators. In our previous study, we reported that NaHS induced NO release from nitrosothiols, namely, S-nitrosoglutathione (GSNO), S-nitroso-N-acetyl-DLpenicillamine and from the metal nitrosyl complex nitroprusside (Ondrias et al. 2008). These results were obtained using electron paramagnetic resonance spectroscopy and by measuring the NO oxidation product (nitrite) using the Griess reaction. We also showed that pretreatment with NaHS (30 $\mu \mathrm{mol} / 1,2-3 \mathrm{~min})$ potentiated the relaxation effect of GSNO on precontracted aortas at $7.5 \mathrm{pH}$. The guanylate cyclase pathway was involved in this effect given that a selective inhibitor of soluble guanylate cyclase ODQ (1H-[1,2,4]oxadiazolo[4,3-a] quinoxalin-1-one) inhibited the NaHS-potentiated relaxation. Exogenously applied NaHS or endogenously produced $\mathrm{H}_{2} \mathrm{~S}$ form a mixture of $\mathrm{H}_{2} \mathrm{~S}, \mathrm{HS}^{-}$and traces of $\mathrm{S}^{2-}$; however, it is not known which form is biologically active. The proportion of $\mathrm{H}_{2} \mathrm{~S}$ decreases with increasing $\mathrm{pH}$, but the proportions of $\mathrm{HS}^{-}$and $\mathrm{S}^{2-}$ increase. The actual concentration of $\mathrm{S}^{2-}$ is very low but increases 100 -fold by changing the $\mathrm{pH}$ from 6.0 to 8.0. As the NO release that was induced by ' $\mathrm{H}_{2} \mathrm{~S}$ ' increased only five- to seven-fold by increasing the $\mathrm{pH}$ from 6.0 to 8.0 in our study, we assumed that $\mathrm{S}^{2-}$ was not the active form of ' $\mathrm{H}_{2} \mathrm{~S}$ '. As the observed NO-releasing effect was more pronounced at $\mathrm{pH} 8.0$ than $\mathrm{pH} 6.0$ and was correlated with the proportion of $\mathrm{HS}^{-}$in the buffer at $\mathrm{pH}$ 6.0, 7.4, and 8.0, we hypothesized that $\mathrm{HS}^{-}$, rather than $\mathrm{H}_{2} \mathrm{~S}$, was responsible for the observed NO release. This model would also explain the pronounced relaxation effect of NaHS at pH 7.5 after the pretreatment of aorta and the minor relaxation effect at $\mathrm{pH}$ 6.3. The $\mathrm{pH}$-dependent effect of NO release from NaHS may be important in the context of both physiological and pathological processes in which $\mathrm{pH}$ plays significant role.

$\mathrm{NO}$, which is synthesized by three isoforms of NO-synthase (NOS), binds to the thiol group of different thiols, such as glutathione, cysteine and albumin, altering their function (Miersch and Mutus 2005). Endogenous nitrosothiols (e.g. GSNO) may act as intermediates in the storage and/or transport of NO to places where it is utilized in smooth muscle cells (Stamler et al. 2001, Ng et al. 2007). Thus, nitroso-compounds serve as stores and carriers of NO as part of the nitroso-signaling pathway (Zhang and Hogg 2005). Similarly to NO, it has been found that $\mathrm{H}_{2} \mathrm{~S}$ can act either directly in a paracrine fashion or be bound to proteins and thus be transported within the organism and released at the target location (Kimura 2010). Bound sulphane-sulphur compounds serve as stores and carriers of $\mathrm{H}_{2} \mathrm{~S}$ (Ishigami et al. 2009). Both high and low $\mathrm{pH}$ and other unknown mechanisms can release $\mathrm{H}_{2} \mathrm{~S}$ that is bound to a protein. This process of $\mathrm{H}_{2} \mathrm{~S}$ transport and function is referred to as sulphidesignaling. As mentioned above, we demonstrated that sulphide-signaling may be directly associated with nitroso-signaling and that protein-bound $\mathrm{H}_{2} \mathrm{~S}$ (or more precisely, protein-bound sulphur) can induce NO release from endogenous NO donors to act in situ (Ondrias et al. 2008). Therefore, sulphide-nitroso signaling occurs, but it is not known whether S-compounds directly release NO from nitroso-compounds or whether $\mathrm{H}_{2} \mathrm{~S}$ released from S-compounds induces NO release. Our subsequent finding was that NaHS $(100 \mu \mathrm{mol} / \mathrm{l})$ induced NO release from several nitroso-compounds (nitroso-cysteine, nitroso-N-acetylcysteine, nitroso-bovine serum albumin) in a concentration-dependent manner, similarly as we previously described for GSNO. Moreover, we observed that $\mathrm{H}_{2} \mathrm{~S}$ led to the generation of a novel modified compound, "unknown interface of nitroso-sulphide signaling pathway" in the vessel wall. This conclusion was reached since preincubation of the vessel wall with low $\mathrm{H}_{2} \mathrm{~S}$ concentrations subsequently led, in the absence 
of $\mathrm{H}_{2} \mathrm{~S}$, to heightened relaxation induced by GSNOderived NO (Bertova et al. 2010). We also showed that the addition of low $\mathrm{H}_{2} \mathrm{~S}$ concentrations (having a slight contractile effect), resulted in the potentiation of $\mathrm{NO}$ release from a nitroso-protein (nitroso-bovine serum albumin) thus leading to the opposite effect, i.e. vasorelaxation. Therefore, $\mathrm{NO}$ and $\mathrm{H}_{2} \mathrm{~S}$ interacted in the tissue to form an unknown complex of nitrosothiols. This complex has physiological properties that are different from the effects of both $\mathrm{NO}$ and $\mathrm{H}_{2} \mathrm{~S}$. We assumed that NO release from nitroso-compounds, either directly by $\mathrm{H}_{2} \mathrm{~S}$ or indirectly by $\mathrm{H}_{2} \mathrm{~S}$-induced sulphur-bound compounds, represents a coupled sulphide-nitroso signaling pathway. Moreover, several authors demonstrated that the mixture of both gases before their application can lead to the generation of a novel compound and eliminate the individual effects of NO and $\mathrm{H}_{2} \mathrm{~S}$. Ali et al. (2006) confirmed that a 1-min mixing of subthreshold concentrations of NaHS $(100 \mu \mathrm{mol} / \mathrm{l})$ with NO donors (sodium nitroprusside, nitrosoacetylpenicillamine, 3-morpholinosydnonimine) resulted in a markedly diminished vasorelaxant effect of each NO donor, providing direct evidence that $\mathrm{H}_{2} \mathrm{~S}$ can quench and thereby inactivate $\mathrm{NO}$ in vitro. The finding that $\mathrm{H}_{2} \mathrm{~S}$ reduces the relaxant effect of three chemically very distinct NO donor molecules pointed to a direct chemical interaction between $\mathrm{H}_{2} \mathrm{~S}$ (derived from $\mathrm{NaHS}$ ) and $\mathrm{NO}$ (derived from $\mathrm{NO}$ donors). $\mathrm{NO}$ and $\mathrm{H}_{2} \mathrm{~S}$ react in aqueous solutions to form a novel, as yet unidentified, nitrosothiol molecule. The direct vasodilator effect of $\mathrm{H}_{2} \mathrm{~S}$ is unstable, transient and primarily observed in in vitro organ bath studies at NaHS concentrations above $100 \mu \mathrm{mol} / \mathrm{l}$. However, plasma concentrations of this gas in both humans and animals are generally in the range of 30-100 $\mu \mathrm{mol} / 1$ (Richardson et al. 2000). These low $\mathrm{H}_{2} \mathrm{~S}$ concentrations are consistent with its ability to interact with NO. It has therefore been suggested that a principal physiological role of $\mathrm{H}_{2} \mathrm{~S}$, released from the vasculature, may be to regulate local concentrations of NO rather than to directly dilate blood vessels. Yong et al. (2010) also found that a mixture of $\mathrm{NO}$ and $\mathrm{H}_{2} \mathrm{~S}$ produced an opposite effect compared with either gas alone. These authors have shown by measuring myocyte contractility that $50 \mathrm{mmol} / \mathrm{l} \mathrm{NaHS}$ had a negligible effect, whereas NO donors produced negative inotropic effects in cardiomyocytes. Unexpectedly, when these two types of donors were mixed, a marked increase in myocyte contractility accompanied by augmented velocities of myocyte contraction and relaxation were observed. $\mathrm{H}_{2} \mathrm{~S}$ might interact with NO to form a thiol-sensitive molecule that produces positive inotropic and lusitropic effects. The nitroxyl anion (HNO) is a potential candidate, but several other compounds have been suggested to mediate the bioactivity of the interaction between S-nitrosothiols and $\mathrm{H}_{2} \mathrm{~S}$. For example, thionitrous acid (HSNO) has been proposed (Filipovic et al. 2012), but the provided evidence appeared to be inconsistent with the known chemical properties of HSNO. Moreover, HSNO would be expected to rapidly react with excess sulphide to form other species (e.g. HNO and hydrogen disulphide); thus, its biological effect would be very short-lived. CorteseKrott et al. (2014) observed that sulphide reacted with S-nitrosothiols to form multiple bioactive products and proposed that nitrosopersulphide (SSNO-) could account for some of the longer-lived effects of the interaction between S-nitrosothiols and $\mathrm{H}_{2} \mathrm{~S}$. $\mathrm{SSNO}^{-}$generated both $\mathrm{NO}$ and polysulphides on decomposition, resulting in a sustained potentiation of nitrosothiol-induced soluble guanylate cyclase stimulation. Cortese-Krott et al. (2015) reported that NO and sulphide form a network of cascading chemical reactions that generate radical intermediates as well as anionic and uncharged solutes, with accumulation of three major products: $\mathrm{SSNO}^{-}$, and dinitrososulfite [N-nitrosohydroxylamine-N-sulfonate (SULFI/NO)], and polysulphides, each with a distinct chemical biology and in vitro and in vivo bioactivity. $\mathrm{SSNO}^{-}$efficiently donates both sulphane sulphur and $\mathrm{NO}$, and potently lowers blood pressure. SULFI/NO is a weak combined $\mathrm{NO}$ /nitroxyl donor that releases mainly nitrous oxide $\left(\mathrm{N}_{2} \mathrm{O}\right)$ on decomposition, although it affects blood pressure only mildly, it markedly increases cardiac contractility, and formation of its precursor sulphite likely contributes to NO scavenging (Cortese-Krott et al. 2015). Polysulphides have recently been shown to exert potent biological effects on a number of targets and may explain, at least in part, some of the effects of endogenously produced $\mathrm{H}_{2} \mathrm{~S}$ and those observed with pharmacological sources of $\mathrm{H}_{2} \mathrm{~S}$ (Greiner et al. 2013, Kimura 2015). We investigated the vascular effects of the longer-lived products of the $\mathrm{H}_{2} \mathrm{~S}-\mathrm{GSNO}$ interaction (Berenyiova et al. 2015). To prepare the reaction products, a 10:1 molar excess of $\mathrm{Na}_{2} \mathrm{~S}$ over GSNO was obtained by mixing equal volumes of $\mathrm{Na}_{2} \mathrm{~S}(20 \mathrm{mmol} / \mathrm{l})$ with GSNO ( $2 \mathrm{mmol} / \mathrm{l})$. We showed that the products of this reaction $(100 \mathrm{nmol} / \mathrm{l})$ relaxed phenylephrineprecontracted isolated rings from the rat thoracic aorta and mesenteric artery with a more than twofold potency compared with GSNO (100 nmol/l) alone. In contrast, 
$\mathrm{Na}_{2} \mathrm{~S}$ and exogenous polysulphides had little effect at 1-5 $\mu \mathrm{mol} / 1$. Moreover, the onset of vasorelaxation of the reaction products was 7-10 times faster compared with GSNO. We also demonstrated that GSNO-induced relaxation (100-500 nmol/l) was blocked by an inhibitor of soluble guanylyl cyclase (ODQ, 0.1 and $10 \mu \mathrm{mol} / \mathrm{l}$ ) and by the NO scavenger cPTIO $(100 \mu \mathrm{mol} / \mathrm{l})$. However, the effect was inhibited to a lesser degree by prior acidification ( $\mathrm{pH}$ 2-4) and was unaffected by the HNO scavengers N-acetylcysteine $(1 \mathrm{mmol} / \mathrm{l})$ and methemoglobin $(20 \mu \mathrm{mol} / \mathrm{l})$. The relaxation induced by $\mathrm{H}_{2} \mathrm{~S}-\mathrm{GSNO}$ reaction products $(100-500 \mathrm{nmol} / \mathrm{l})$ was inhibited by ODQ, slightly decreased by cPTIO, markedly inhibited by $\mathrm{N}$-acetylcysteine and methemoglobin, and abolished by acidification of the reactants before addition to the organ bath. Therefore, while GSNO and the product(s) of its chemical interaction with $\mathrm{H}_{2} \mathrm{~S}$ both act via stimulation of soluble guanylate cyclase, their relaxation profiles were differentially modulated by NO scavengers, HNO scavengers and $\mathrm{pH}$. These results strongly suggest the involvement of more than one product (in the reaction mixture) in mediating cGMP activation and vasorelaxation. While NO was clearly demonstrated (using EPR spectra) to be involved in vasorelaxation, a significant portion of the relaxation induced by the $\mathrm{H}_{2} \mathrm{~S}$ GSNO reaction products was mediated by a free NO-independent mechanism that directly activated soluble guanylate cyclase. Because these effects are reminiscent of those of the HNO donor Angeli's salt (Bobko et al. 2014), we suggested that $\mathrm{HNO}$, as another reactive intermediate, may be involved in the relaxation effects induced by the mixture of both gases. Moreover, as the products of the $\mathrm{H}_{2} \mathrm{~S}-\mathrm{GSNO}$ interaction were applied 3 min after mixing, at which time no further absorbance changes were seen based on EPR measurements, relatively long-lived reaction product(s) must also be involved in the observed relaxation. These products may include polysulphides and $\mathrm{SSNO}^{-}$. Given that polysulphides, at the concentrations expected to prevail in the reaction mixture, did not induce vasorelaxation under comparable conditions, $\mathrm{SSNO}^{-}$ appeared to account for the remaining relaxation effects of the reaction products. Nevertheless, whether any of these compounds contribute to the biological cross-talk between sulphide and NO in the cardiovascular system warrants further investigation.

The literature suggests that $\mathrm{H}_{2} \mathrm{~S}$ and $\mathrm{NO}$ can also react in the context of their endogenous production. Ali et al. (2006) showed that an i.v. infusion of NaHS $(25 \mathrm{mmol} / \mathrm{kg} / \mathrm{min})$ lowered blood pressure in rats, whereas an infusion of a low dose of NaHS $(10 \mathrm{mmol} / \mathrm{kg} / \mathrm{min})$ increased blood pressure. The effect was relatively small $(10-15 \mathrm{~mm} \mathrm{Hg})$ but was statistically significant and was maintained for several minutes. The vasopressor activity of NaHS was abolished in animals that were pretreated with L-NAME $(25 \mathrm{mg} / \mathrm{kg}$ i.v. $)$ to inhibit endogenous NO biosynthesis. This suggests that $\mathrm{H}_{2} \mathrm{~S}$ (derived from NaHS) quenched endogenous endothelium-derived NO, leading to a loss of NO-derived vasodilator tone and increased blood pressure. Similarly, Kubo et al. (2007) showed that NaHS induced the inhibition of eNOS activity in the arterial walls of rat and mouse aortas, and this effect was associated with an increase in arterial tension. Following L-NAME pretreatment, no vasoconstricting effect was observed. They also compared the effect of cumulative doses of NaHS (1-300 $\mu \mathrm{mol} / \mathrm{l})$ on endothelium-dependent and -independent vasorelaxant responses in the thoracic aorta. Their data showed that pretreatment with a $\mathrm{H}_{2} \mathrm{~S}$ donor significantly inhibited acetylcholine-induced vasorelaxation but did not affect the vasorelaxation effects of sodium nitroprusside. The authors suggested that low $\mathrm{H}_{2} \mathrm{~S}$ concentrations inhibited eNOS activity in the presence of endogenously produced NO, possibly via an interaction between $\mathrm{H}_{2} \mathrm{~S}$ and NOS cofactors, such as NADPH or tetrahydrobiopterin. On the other hand, Zhao et al. (2001, 2003) demonstrated that the NO donor sodium nitroprusside upregulated $\mathrm{H}_{2} \mathrm{~S}$ production by increasing CSE expression and activity in rat vascular tissues in a concentration-dependent manner. Geng et al. (2007) showed that NaHS inhibited NO generation in cultured aortic tissue and that low NaHS doses downregulated the L-arginine/NO pathway 1) by inhibiting endothelial NOS expression and L-arginine transporter and/or 2) by decreasing NOS activity. According to these findings, it appears that the interaction between the endogenous production pathways of both transmitters ensures the maintenance of a dynamic balance. This interaction consists of a negative feedback loop in which $\mathrm{NO}$ stimulates $\mathrm{H}_{2} \mathrm{~S}$ production and increased $\mathrm{H}_{2} \mathrm{~S}$ levels inhibit endogenous NO production and activity.

Among the data on the opposing effects of $\mathrm{H}_{2} \mathrm{~S}$ are results indicating the participation of $\mathrm{NO} / \mathrm{NOS}$ in $\mathrm{H}_{2} \mathrm{~S}$-induced vasorelaxation and the potentiation of NO pathway by $\mathrm{H}_{2} \mathrm{~S}$. Zhao et al. (2001) demonstrated that $\mathrm{H}_{2} \mathrm{~S}$ relaxed rat aortic tissues in vitro in a $\mathrm{K}_{\mathrm{ATP}}$ channeldependent manner. Nevertheless, a small portion of the 
vasorelaxant effect of $\mathrm{H}_{2} \mathrm{~S}$ was potentiated by the endothelium, indicating that $\mathrm{H}_{2} \mathrm{~S}$ might act as an endothelium-dependent hyperpolarizing factor (EDHF). Zhao and Wang (2002) demonstrated that vasorelaxant potency of $\mathrm{H}_{2} \mathrm{~S}(0.01-1 \mathrm{mmol} / \mathrm{l})$ was attenuated by the removal of the endothelium and by blocking $\mathrm{NO}$ synthesis after L-NAME addition. Contrary to the findings of Hosoki et al. (1997), these authors showed that pretreatment of rat aortic tissues with $60 \mu \mathrm{mol} / 1 \mathrm{H}_{2} \mathrm{~S}$ shifted the concentration-response curve for sodium nitroprusside to the right, revealing that $\mathrm{H}_{2} \mathrm{~S}$ inhibited the vasorelaxant effect of the NO donor. The discrepancy between these results could result from different experimental conditions, i.e. the tissue preparation procedure and/or the level of vascular tone after precontraction. Nevertheless, this study indicated that both the endothelium and vascular smooth muscle may serve as targets of $\mathrm{H}_{2} \mathrm{~S}$. As denervation does not alter the effects of $\mathrm{H}_{2} \mathrm{~S}$ effect and the molecule can still significantly relax vascular tissue after endothelium removal, it has been proposed that the vasorelaxant effects of $\mathrm{H}_{2} \mathrm{~S}$ are primarily due to its direct interaction with smooth muscle cells. Moreover, $\mathrm{H}_{2} \mathrm{~S}$ can relax vascular tissue independent of the activation of cGMP pathway but requires calcium handling. Therefore, by acting on the endothelium, $\mathrm{H}_{2} \mathrm{~S}$ may facilitate the release of vasorelaxant factors, including $\mathrm{NO}$ and EDHF, and by acting directly on vascular smooth muscle cells, $\mathrm{H}_{2} \mathrm{~S}$ may reduce extracellular calcium entry and relax vascular tissues (Zhao and Wang 2002). Coletta et al. (2012) showed that the inhibition of endothelial isoform of NOS attenuated $\mathrm{H}_{2} \mathrm{~S}$-stimulated vasorelaxation, demonstrating the requirement of $\mathrm{NO}$ in vascular $\mathrm{H}_{2} \mathrm{~S}$ signaling. Conversely, silencing the $\mathrm{H}_{2} \mathrm{~S}$-producing enzyme CSE abolished NO-stimulated cGMP accumulation and attenuated acetylcholine-induced vasorelaxation, indicating a partial requirement of $\mathrm{H}_{2} \mathrm{~S}$ in the vascular activity of NO. The actions of $\mathrm{H}_{2} \mathrm{~S}$ and $\mathrm{NO}$ converged at cGMP because $\mathrm{H}_{2} \mathrm{~S}$ maintained a tonic inhibitory effect on phosphodiesterase type 5 (PDE-5), thereby delaying cGMP degradation. It has also been confirmed in chronic experiments that $\mathrm{NO}$ and $\mathrm{H}_{2} \mathrm{~S}$ are mutually required for the physiological control of vascular function. Zhao et al. (2003) demonstrated dysfunction of the vascular $\mathrm{H}_{2} \mathrm{~S}$ synthesis/ $\mathrm{H}_{2} \mathrm{~S}$ pathway in L-NAME-induced hypertensive rats. They showed that a 6-week administration of L-NAME to Wistar rats induced the downregulation of CSE gene expression followed by decreased CSE activity. This treatment also reduced $\mathrm{H}_{2} \mathrm{~S}$ generation in the thoracic aorta and superior mesenteric artery as well as $\mathrm{H}_{2} \mathrm{~S}$ plasma levels. Moreover, exogenous $\mathrm{H}_{2} \mathrm{~S}$ effectively prevented the development of L-NAMEinduced hypertension. These findings suggest that $\mathrm{H}_{2} \mathrm{~S}$ synthesis and the $\mathrm{H}_{2} \mathrm{~S}$ pathway participated in $\mathrm{NO}$ deficiency-induced hypertension.

\section{$\mathrm{H}_{2} \mathrm{~S}$ in hypertension}

The effects of $\mathrm{H}_{2} \mathrm{~S}$ on blood pressure are characterized by considerable heterogeneity due to the concentration-dependent effects of $\mathrm{H}_{2} \mathrm{~S}$. It was reported that acute intravenous addition of high concentrations of exogenous $\mathrm{H}_{2} \mathrm{~S}$-donors $(>10 \mu \mathrm{mol} / \mathrm{kg})$ reduce blood pressure (Zhao et al. 2001), while low concentrations of NaHS $(<10 \mu \mathrm{mol} / \mathrm{kg})$ induce a significant increase (Ali et al. 2006). Slow $\mathrm{H}_{2} \mathrm{~S}$-donor AP39 decreased and consequently increased blood pressure at $0.2-1.0 \mu \mathrm{mol} / \mathrm{kg}$ (Tomasova et al. 2015). Our in vivo experiments showed that intravenously injected $\mathrm{Na}_{2} \mathrm{~S} \quad(3 \mu \mathrm{mol} / \mathrm{kg})$ had vasopressor effects only; however, at higher $\mathrm{Na}_{2} \mathrm{~S}$ doses (8-30 $\mu \mathrm{mol} / \mathrm{kg}$ ), we demonstrated a transient biphasic effect on blood pressure (Drobna et al. 2015). The $\mathrm{K}_{\text {ATP }}$ channel has been reported to be a major molecular target of the vasorelaxant and vasodepressor effects of $\mathrm{H}_{2} \mathrm{~S}$ (Zhao et al. 2001). We confirmed this finding using glibenclamide, a $\mathrm{K}_{\mathrm{ATP}}$ channel inhibitor. Specifically, this inhibitor blocked the vasorelaxation induced by higher doses of $\mathrm{H}_{2} \mathrm{~S}$ (Drobna et al. 2015). Given that 1) acute pretreatment with glibenclamide did not affect low-dose $\mathrm{H}_{2} \mathrm{~S}$-induced contractile responses of isolated thoracic aortas and 2) the increase in blood pressure was observed at lower $\mathrm{H}_{2} \mathrm{~S}$ concentrations than the biphasic effects, we concluded that $\mathrm{K}_{\mathrm{ATP}}$ channels were not involved in the transient blood pressure increase. The increased phase of biphasic blood pressure response to $\mathrm{H}_{2} \mathrm{~S}$ could be associated with a sympathetic reflex response. This hypothesis is consistent with reports on several vasoactive substances, such as endothelin, urotensin and apelin (King et al. 1990, Gardiner et al. 2004, Charles et al. 2006). Gines et al. (1994) also suggested that the sympathetic reflex vasopressor response observed after intravenous acetylcholine injection resulted from pressure receptor stimulation following the detection of arterial hypotension. Moreover, some baroreceptors are membrane channels, which are influenced by $\mathrm{H}_{2} \mathrm{~S}$. Therefore, it could be hypothesized that $\mathrm{H}_{2} \mathrm{~S}$ influences baroreceptors through its action on membrane channels (Malekova et al. 2009, Peers et al. 2012). 
Commonly used $\mathrm{H}_{2} \mathrm{~S}$ donors (NaHS and $\mathrm{Na}_{2} \mathrm{~S}$ ) release a large amount of $\mathrm{H}_{2} \mathrm{~S}$ in a few seconds. Hence, the relevant tissue comes into the contact with high concentrations of $\mathrm{H}_{2} \mathrm{~S}$, the effect of which is time-limited and non-physiological. Therefore, under the physiological conditions, when the concentration of $\mathrm{H}_{2} \mathrm{~S}$ within the bloodstream is in the nanomolar range $(<20 \mathrm{nmol} / \mathrm{l}), \mathrm{H}_{2} \mathrm{~S}$ likely evokes vasoconstricting and hypertensive effects. Nevertheless, the exogenous administration of $\mathrm{H}_{2} \mathrm{~S}$ to adult spontaneously hypertensive rats (SHR) partially inhibited both the development of hypertension and aortic structural remodeling (Yan et al. 2004)). They also demonstrated significantly lower plasma $\mathrm{H}_{2} \mathrm{~S}$ levels and a partially modified synthesis of $\mathrm{H}_{2} \mathrm{~S}$. This latter effect was caused by changes in gene expression and the inhibition of CSE expression in this strain. Moreover, chronic treatment with NaHS as well as with a slowreleasing $\mathrm{H}_{2} \mathrm{~S}$ donor (GYY4137) induced a significant decrease in blood pressure (Shi et al. 2007, Li et al. 2008). All of these findings suggest that $\mathrm{H}_{2} \mathrm{~S}$ is engaged in the etiopathogenesis of hypertension.

Lu et al. (2010) showed that the intraperitoneal administration of NaHS significantly reduced the development of hypertension in two-kidney-one-clip (2K1C) rats, which represent a model of renovascular hypertension. This animal model is characterized by increased production of renin, and plasma levels of angiotensin II are 5-fold higher than in normal rats. The authors confirmed that NaHS inhibited plasma renin activity in these rats and that the $\mathrm{H}_{2} \mathrm{~S}$-induced reduction of degranulation and renin release was mediated by the inhibition of adenylate cyclase activity and cAMP synthesis. In contrast, NaHS did not affect blood pressure or plasma renin activity in normal or one-kidney-one-clip (1K1C) rats, both of which exhibited normal plasma renin activity ( $\mathrm{Lu}$ et al. 2012). Moreover, $\mathrm{H}_{2} \mathrm{~S}$ can react with metal ions (i.e. $\mathrm{Cu}, \mathrm{Fe}, \mathrm{Zn}$ ) in metalloproteins. The angiotensin-converting enzyme (ACE), which is responsible for vasoconstriction, is a zinc-containing enzyme. Laggner et al. (2007) proved that $\mathrm{H}_{2} \mathrm{~S}$ directly inhibited ACE activity in monolayers of cultured human umbilical vein endothelial cells by interfering with the zinc atom in the active centre of ACE. $\mathrm{H}_{2} \mathrm{~S}$ thereby reduced angiotensin II production and inhibited bradykinin degradation. NaHS also negatively influenced the binding of angiotensin II to its $\mathrm{AT}_{1}$ receptor by reducing the affinity of the reaction. NaHS also inhibited oxidative stress signaling pathways, an effect that was associated with an inhibitory effect on smooth muscle proliferation and collagen generation (Zhao et al. 2008). These data suggest that the inhibition of different components of the renin-angiotensin system (RAS) could play a crucial role in the antihypertensive effect of $\mathrm{H}_{2} \mathrm{~S}$. RAS plays a key role in the development of essential hypertension, and its interaction with $\mathrm{H}_{2} \mathrm{~S}$ appears to be a possible mechanism of $\mathrm{H}_{2} \mathrm{~S}$ involvement in the etiopathogenesis of hypertension. Our recent findings also support the above-mentioned hypothesis. We observed that a bolus administration of captopril (an angiotensin-converting enzyme inhibitor) in vivo reduced the $\mathrm{H}_{2} \mathrm{~S}$ donor-induced decrease in blood pressure. This result suggests that captopril might inhibit the mechanism responsible for the depressor effect of $\mathrm{H}_{2} \mathrm{~S}$ (Drobna et al. 2015). We suggested that captopril disabled the inhibitory effect of $\mathrm{H}_{2} \mathrm{~S}$ on RAS, thereby masking the depressor effects of $\mathrm{H}_{2} \mathrm{~S}$. As acetylcholine decreased blood pressure to the same extent as before captopril treatment, we assumed that a change in the blood pressure baseline after captopril administration was not responsible for the weaker $\mathrm{H}_{2} \mathrm{~S}$ effect. Nevertheless, as the effect of $\mathrm{H}_{2} \mathrm{~S}$ was reduced but not blocked by captopril, we suggested that the RAS was only partially involved. Moreover, the associations between $\mathrm{H}_{2} \mathrm{~S}$, the baroreflex mechanism and the autonomic nervous system should also be taken into account. Increases in angiotensin II levels in the central nervous system have been shown to affect arterial baroreflex control and to increase the sympathetic outflow (Gao et al. 2005). Because the administration of captopril inhibited angiotensin II synthesis, this compound may have masked the partial baroreflex-mediated effects of $\mathrm{H}_{2} \mathrm{~S}$. Moreover, Grman et al. (2013) and Drobna et al. (2015) observed that captopril inhibited $\mathrm{H}_{2} \mathrm{~S}$-induced $\mathrm{NO}$ release from low molecular thiols, such as cysteine, Nacetylcysteine, glutathione and GSNO. As captopril contains a thiol moiety, it is possible that captopril interfered with $\mathrm{NO}$ signaling via this pathway. We previously showed that 1) $\mathrm{H}_{2} \mathrm{~S}$ caused $\mathrm{NO}$ release from NO donors, increasing their vasorelaxant effects (Ondrias et al. 2008, Bertova et al. 2010), and 2) $\mathrm{Na}_{2} \mathrm{~S}$-induced blood pressure decrease at transient $\mathrm{Na}_{2} \mathrm{~S}$ blood concentrations can be triggered via NO release from GSNO (Drobna et al. 2015). If we assume that the transient presence of $\mathrm{H}_{2} \mathrm{~S}$ led to the release of $\mathrm{NO}$ from endogenous NO-donors, then inhibiting NO release from these sources after captopril addition should also be considered. Using the Griess assay and UV-VIS spectrometry, we confirmed that captopril decreased $\mathrm{H}_{2} \mathrm{~S}$-induced $\mathrm{NO}$ release from GSNO at $\mathrm{pH} 7.4$ in vitro. We therefore hypothesized that this effect could contribute to the attenuated blood pressure decrease. This 

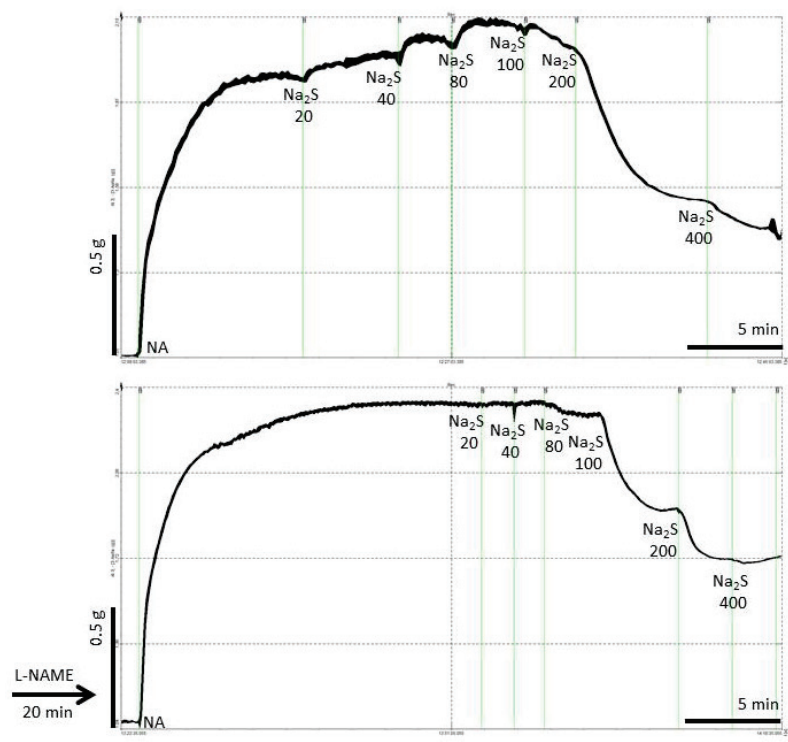
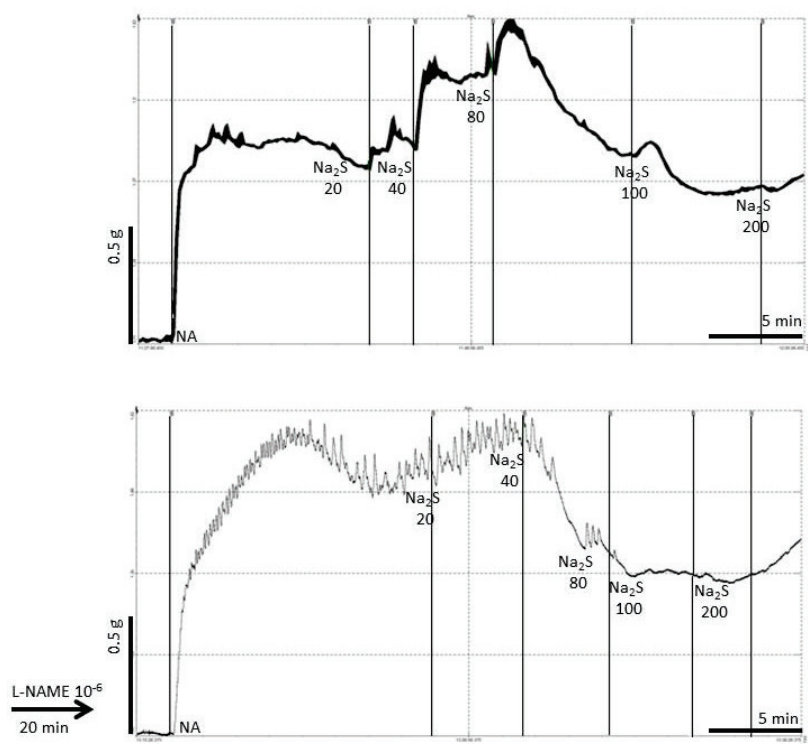

Fig. 1. The original record of changes in noradrenaline (NA, $1 \mu \mathrm{mol} / \mathrm{l})$-increased arterial tone which were induced by cumulative concentrations of $\mathrm{Na}_{2} \mathrm{~S}(20-200 \mu \mathrm{mol} / \mathrm{l})$ in Wistar rats (left panels) and SHR (right panels) before (upper panels) and after (lower panels) acute addition of NO-synthase inhibitor L-NAME $(1 \mu \mathrm{mol} / \mathrm{l})$.

idea is also supported by the observation that captopril interferes with the NO pathway and that the captopril thiol group was found to be important in preventing spontaneous hypertension (Pecháňová et al. 2007).

As mentioned, $\mathrm{H}_{2} \mathrm{~S}$ induces a biphasic vasoactive effect. Specifically, while low concentrations evoke contractile responses, high concentrations induce relaxation of the arterial wall. However, the information on the role of $\mathrm{H}_{2} \mathrm{~S}$ and its possible interactions with $\mathrm{NO}$ in the developmental stage of spontaneous hypertension has not been published. We compared the vasoactive effect of $\mathrm{Na}_{2} \mathrm{~S}$ (applied at concentrations of 20, 40, 80, 100,200 and $400 \mu \mathrm{mol} / \mathrm{l}$ ) on the responses of isolated thoracic aortas in 4-week-old normotensive rats and SHRs. We showed that in 4-week-old Wistar rats, $\mathrm{Na}_{2} \mathrm{~S}$ concentrations of $20-80 \mu \mathrm{mol} / 1$ induced vasoconstriction, whereas $100-400 \mu \mathrm{mol} / 1$ led to vasorelaxation. On the other hand, in young SHRs, contractile responses were obtained at concentrations of $20-40 \mu \mathrm{mol} / 1$ and vasorelaxation at $80 \mu \mathrm{mol} / \mathrm{l}$. This dose-dependent shift confirmed that $\mathrm{H}_{2} \mathrm{~S}$ regulates arterial tone in favor of vasorelaxation in young prehypertensive rats (Berenyiova et al. 2013). We also evaluated the effect of the acute inhibition of endogenous $\mathrm{NO}$ production on $\mathrm{H}_{2} \mathrm{~S}$-induced vasoactive responses. Pretreatment with L-NAME diminished the contractile component of vasoactive effects of $\mathrm{H}_{2} \mathrm{~S}$ and increased the relaxant component in young normotensive rats as well as prehypertensive SHRs (Fig. 1). These results are in agreement with findings that NO-independent pathways, predominantly
$\mathrm{K}_{\mathrm{ATP}}$ activation, are responsible for the vasorelaxing effects of $\mathrm{H}_{2} \mathrm{~S}$ (Zhao et al. 2001, Drobna et al. 2015). On the other hand, we suppose that the $\mathrm{H}_{2} \mathrm{~S}$ induced vasoconstriction in our experiment is very probably associated with inhibitory action of $\mathrm{H}_{2} \mathrm{~S}$ on endogenously produced NO. Kubo et al. (2007) observed similar results in 7- to 9-week-old Wistar rats, reporting that pretreatment with NaHS led to enhanced phenylephrineinduced contraction in endothelium-preserved thoracic aortas. Moreover, this NaHS-evoked enhancement was significantly decreased by pretreatment with L-NAME. As mentioned above, other experiments have shown that the vasoconstricting effects of $\mathrm{H}_{2} \mathrm{~S}$ may depend on the presence of endogenously synthesized NO (Ali et al. 2006). Several authors have confirmed in both cultured and isolated vascular tissues of normotensive animals that $\mathrm{H}_{2} \mathrm{~S}$ donors downregulate the L-arginine/NO pathway via several mechanisms (Geng et al. 2007, Kubo et al. 2007). In our experiment, we suggested that acute pretreatment with L-NAME disabled the inhibitory effect of $\mathrm{H}_{2} \mathrm{~S}$ on NO production, masking the contractile effects of $\mathrm{H}_{2} \mathrm{~S}$ not only in Wistar rats but also in SHRs. Moreover, our results confirmed that this effect was stronger in SHRs. In young prehypertensive rats, $\mathrm{H}_{2} \mathrm{~S}$ regulated the arterial tone towards of vasorelaxant phase, and this effect was accentuated after the inhibition of endogenous NO. We showed that the pretreatment with L-NAME changed the contractile response to the relaxation in both strains. This switch-over was shifted to lower $\mathrm{Na}_{2} \mathrm{~S}$ concentration in SHR $(40 \mu \mathrm{mol} / \mathrm{l})$ compared to Wistar rats $(80 \mu \mathrm{mol} / \mathrm{l})$. 
These effects could be a part of the compensatory mechanisms triggered in SHRs to counter-regulate the increased vascular tone. Indeed, recent studies have shown that SHRs very likely have a unique genetic program that has compensatory and adaptive effects during the later developmental stage of hypertension. Increased activity of NO system is thought to be one of the compensatory mechanisms during increased blood pressure and arterial tonus. This hypothesis was confirmed by a study of Zhao et al. (2012), who observed reduced contractile responses of thoracic aortas in SHRs compared to normotensive rats. Only in SHRs was inhibited vasoconstriction associated with the ability of endothelial cells to release a vasoconstriction-reducing compound. The authors also showed that the endothelium-released substance that reduced arterial tone was NO that was not synthesized by NO synthase. Other experiments demonstrated that compared to normotensive rats, SHRs generated higher level of nitrites and nitrates, which represent NOS-independent NO sources (Wu and Yen 1999). These molecules can substitute for bioactive nitrous oxide, including NO. Zhao et al. (2012) confirmed that the alternative production of $\mathrm{NO}$ from nitrites and nitrates represents a compensatory effect of the arterial wall to overcome insufficient synthesis of NO by endothelial NOS during hypertension. Moreover, our previous findings confirmed that the arterial wall produces physiologically active NO not only by endothelial but also by smooth muscle cells, where the expression of two NOS isoforms was confirmed (Buchwalow et al. 2008, Cacanyiova et al. 2013). These results showed that non-endothelial NO production could represent an additional compensatory mechanism to ensure vasorelaxant responses when NO produced by endothelial sources is eliminated by the increased production of free radicals (Cacanyiova et al. 2013). Consistent with this hypothesis, Boulanger et al. (1998) demonstrated in the carotid artery of SHRs that the neuronal NOS isoform was activated in vascular smooth muscle cells upon stimulation by angiotensin and could compensate for a weakened endothelial response; this was not observed in normotensive animals. Our finding of increased arterial sensitivity to $\mathrm{H}_{2} \mathrm{~S}$ in favor of vasorelaxation in young SHRs compared to normotensive rats is consistent with the above-mentioned findings and confirms that endothelium-regulated compensatory mechanisms have already been triggered in the crucial juvenile stage of hypertension progression.

The lipid composition of biological membranes is crucial for many aspects of organelle function. Fatty acids are a major energy source and are important constituents of membrane lipids, serving as cellular signaling molecules. $\mathrm{H}_{2} \mathrm{~S}$ is soluble in lipids and readily crosses membranes. We found that lipids and fatty acids can affect the modulator effect of $\mathrm{H}_{2} \mathrm{~S}$ on $\mathrm{NO}$ release from nitroso-compounds, and this effect depends on the particular lipid or fatty acid used. Unsaturated fatty acid, linoleic acid, and lipids with unsaturated fatty acids (asolectin) depressed NaHSinduced NO release from GSNO. Alternatively, the depressive effects of myristic acid (a saturated fatty acid) and lipids with saturated fatty acids were less pronounced (Tomaskova et al. 2009). This result may indicate an important role of the composition of membrane lipids in the environment in which $\mathrm{H}_{2} \mathrm{~S}$ is produced. We propose that the products of $\mathrm{NaHS}, \mathrm{H}_{2} \mathrm{~S}, \mathrm{HS}^{-}$and/or $\mathrm{S}^{2-}$ may chemically interact with the unsaturated bonds of fatty acids and thereby decrease the effective $\mathrm{H}_{2} \mathrm{~S}$ concentration that can interact with GSNO. This effect could inhibit the $\mathrm{H}_{2} \mathrm{~S}$-induced potentiation of vasorelaxation. Moreover, Muellner et al. (2009) showed that $\mathrm{H}_{2} \mathrm{~S}$ may act as an antiatherogenic agent by reducing highly reactive lipid hydroperoxides in oxidized LDL, thereby abrogating their pathological activity. Therefore, the quenching of $\mathrm{H}_{2} \mathrm{~S}$ by unsaturated fatty acids could inhibit the attenuation of lipid hydroperoxide formation. Moreover, the primary step in sulphide reactions is the electron transfer from $\mathrm{H}_{2} \mathrm{~S} / \mathrm{HS}$ species to a suitable acceptor, e.g. $\mathrm{O}_{2}$, thereby producing $\mathrm{HS}^{*}$ and $\mathrm{S}^{--}$radicals. Stasko et al. (2009) and Lykakis et al. (2007) demonstrated the potential of $\mathrm{HS}^{-}$and $\mathrm{S}^{--}$radicals derived from $\mathrm{H}_{2} \mathrm{~S}$ to access hydrophobic fatty acid chains and attack the double bonds, isomerising the double bonds in cell membrane lipids and leading to their instability. An altered lipid membrane composition as a result of disordered lipid metabolism and altered fatty acid metabolism is connected to several diseases, such as obesity, hypertension, diabetes mellitus and others (Das 2006).

Whiteman et al. (2010) confirmed that the concentration of $\mathrm{H}_{2} \mathrm{~S}$ in human plasma was reduced in patients with diabetes mellitus type II and that adiposity, obesity and overweight were determinants of this effect. We performed pilot experiments on renal arteries isolated from humans suffering from arterial hypertension, showing that a mixture of exogenous $\mathrm{NO}$ and $\mathrm{H}_{2} \mathrm{~S}$ induced a vasorelaxant effect. This effect not only differed from that observed in isolated rat thoracic aortas (Berenyiova et al. 2015) but was also modulated by a patient's metabolic malfunction (e.g. diabetes mellitus 
or hypercholesterolemia) or obesity. Obesity, which is an important risk factor in the development of hypertension, is characterized by excessive and abnormal adipose tissue accumulation, including perivascular adipose tissue. Perivascular adipose tissue is a local deposit of adipose tissue that surrounds the vasculature. This tissue is metabolically active and secretes a wide array of bioactive substances, termed adipokines. $\mathrm{H}_{2} \mathrm{~S}$ was identified as an adipocyte-derived relaxing factor (Schleifenbaum et al. 2010), and adipokines produced by perivascular adipose tissue may affect the endothelial function of arteries (Ma et al. 2016). Human studies showed that this tissue is physiologically active and produces beneficial compounds. Nevertheless, it appears that the balance among lipid metabolism, which involves adipose deposits in the arterial wall, and $\mathrm{H}_{2} \mathrm{~S}$ signaling pathways and endothelial function, could be injured in pathological conditions. However, further studies are required to substantiate the precise relationship between these factors and their roles in various pathologies.

\section{Conclusions}

$\mathrm{H}_{2} \mathrm{~S}$ and NO interact on different levels, acting on both arterial smooth muscle cells and endothelial cells and modulating the chemical structure of endogenous proteins. Some of the affected proteins include the enzymes responsible for the endogenous production of these signaling molecules, which regulate and maintain vascular homeostasis and dynamic balance. Imbalances in this network may contribute to the pathogenesis of cardiovascular diseases. Research into the regulation of the interaction between these gases will likely reveal novel avenues for understanding the pathological mechanisms of cardiovascular diseases and for the development of novel prevention and treatment strategies.

\section{Conflict of Interest}

There is no conflict of interest.

\section{Acknowledgements}

Financial support by Slovak grants VEGA 2/0074/14, 2/0067/13, Ministry of Health of the Slovak Republic under the project registration number 2012/51-SAV-1 and APVV-15-0565 is gratefully acknowledged. We thank L. Kosnacova for her technical assistance.

\section{Abbreviations}

$1 \mathrm{~K} 1 \mathrm{C}$ rats - one-kidney-one-clip rats
2K1C rats - two-kidney-one-clip rats

3-MST - mercaptopyruvate-sulphurtransferase

ACE - angiotensin-converting enzyme

$\mathrm{AT}_{1}$ - angiotensine II receptor type 1

ATP - adenosine triphosphate

$\mathrm{BK}_{\mathrm{Ca}}$ - big conductance $\mathrm{Ca}^{2+}$-activated $\mathrm{K}^{+}$channel

cAMP - cyclic adenosine monophosphate

CAT - cysteine-aminotransferase

CBS - cystathionine $\beta$-synthase

cGMP - cyclic guanosine monophosphate

$\mathrm{Cl}^{-} / \mathrm{HCO}_{3}^{-}-$bicarbonate transporter protein

$\mathrm{CO}$ - carbon monoxide

$\mathrm{CO}_{2}-$ carbon dioxide

cPTIO - 2-(4-Carboxyphenyl)-4,4,5,5-tetramethylimidazoline-1-oxyl-3-oxide

CSE - cystathionine $\gamma$-lyase

DEA/NO - 2-(N,N-diethylamino)-diazenolate-2-oxide

EDHF - endothelium-dependent hyperpolarizing factor

eNOS - endothelial NO-synthase

EPR - electron paramagnetic resonance

GSNO - S-nitrosogluthatione

$\mathrm{H}_{2} \mathrm{~S}$ - hydrogen sulphide

$\mathrm{HNO}$ - nitroxyl anion

$\mathrm{HS}^{-}$- hydrosulfide ion

HS - hydrosulfide radical

HSNO - thionitrous acid

$\mathrm{IK}_{\mathrm{Ca}}$ - intermediate conductance $\mathrm{Ca}^{2+}$-activated $\mathrm{K}^{+}$ channel

$\mathrm{K}_{\mathrm{ATP}}$ - ATP-sensitive $\mathrm{K}^{+}$channel

$\mathrm{KCNQ}$ - subfamily of voltage-gated $\mathrm{K}^{+}$channels

$\mathrm{K}_{\mathrm{V}}$ - voltage-gated $\mathrm{K}^{+}$channel

LDL - low density lipoprotein

L-NAME - $\mathrm{N}^{\mathrm{G}}$-nitro-L-arginine-methylester

$\mathrm{N}_{2} \mathrm{O}$ - nitrous oxide

$\mathrm{Na}_{2} \mathrm{~S}$ - sodium sulphide

$\mathrm{NADPH}$ - nicotinamide adenine dinucleotide phosphate

NaHS - sodium hydrosulphide

$\mathrm{NO}$ - nitric oxide

NOS - NO-synthase

$\mathrm{O}_{2}$ - diatomic oxygen

ODQ - 1H-[1,2,4]oxadiazolo[4,3- a]quinoxalin-1-one

PDE - phosphodiesterase

PDE-5 - phosphodiesterase type 5

RAS - renin-angiotensin system

$\mathrm{S}^{2-}$ - sulphide dianion

SHR - spontaneously hypertensive rats

$\mathrm{SK}_{\mathrm{Ca}}$ - small conductance $\mathrm{Ca}^{2+}$-activated $\mathrm{K}^{+}$channel

$\mathrm{SSNO}^{-}$- nitrosopersulphide

SULFI/NO - N-nitrosohydroxylamine-N-sulfonate 


\section{References}

ABE K, KIMURA H: The possible role of hydrogen sulfide as an endogenous neuromodulator. $J$ Neurosci 16: 10661071, 1996.

ALI MY, PING CY, MOK YY, LING L, WHITEMAN M, BHATIA M, MOORE PK: Regulation of vascular nitric oxide in vitro and in vivo; a new role for endogenous hydrogen sulphide? Br J Pharmacol 149: 625-634, 2006.

BERENYIOVA A, CACANYIOVA S, KRISTEK F, MALEKOVA M: Vasoactive effect of $\mathrm{NO}$ and $\mathrm{H}_{2} \mathrm{~S}$ interaction on thoracic aorta in young normotensive and spontaneously hypertensive rats. Cardiol Lett 22: 11S-12S, 2013.

BERENYIOVA A, GRMAN M, MIJUSJOVIC A, STASKO A, MISAK A, NAGY P, ONDRAISOVA E, CACANYIOVA S, BREZOVA V, FEELISCH M, ONDRIAS K: The reaction products of sulfide and S-nitrosoglutathione are potent vasorelaxants. Nitric Oxide 46: 123-130, 2015.

BERTOVA A, CACANYIOVA S, KRISTEK F, KRIZANOVA O, ONDRIAS K, TOMASKOVA Z: The hypothesis of the main role of $\mathrm{H}_{2} \mathrm{~S}$ in coupled sulphide-nitroso signalling pathway. Gen Physiol Biophys 29: 402-410, 2010.

BOBKO AA, KHRAMTSOV VV: Mechanistic studies of oxidative decomposition of Angeli's salt and PAPA NONOate. Nitric Oxide 40: 92-98, 2014.

BOULANGER CM, HEYMES C, BENESSIANO J, GESKE RS, LEVY BI, VANHOUTTE PM: Neuronal nitric oxide synthase is expressed in rat vascular smooth muscle cells: activation by angiotensin II in hypertension. Circ Res 83: 1271-1278, 1998.

BUCCI M, PAPAPETROPOULOS A, VELLECCO V, ZHOU Z, PYRIOCHOU A, ROUSSOS C, ROVIEZZO F, BRANCALEONE V, CIRINO G: Hydrogen sulfide is an endogenous inhibitor of phosphodiesterase activity. Arterioscler Thromb Vasc Biol 30: 1998-2004, 2010.

BUCHWALOW LB, CACANYIOVA S, NEUMANN J, SAMOILOVA VE, BOECKER W, KRISTEK F: The role of arterial smooth muscle in vasorelaxation. Biochem Biophy Res Commun 377: 504-507, 2008.

CACANYIOVA S, DOVINOVA I, KRISTEK F: The role of oxidative stress in acetylcholine-induced relaxation of endothelium-denuded arteries. J Physiol Pharmacol 64: 241-247, 2013.

CHARLES CJ, RADEMAKER MT, RICHARDS AM: Apelin 13 induces a biphasic haemodynamic response and hormonal activation in normal conscious sheep. $J$ Endocrinol 189: 701-710, 2006.

CHEANG WS, WONG WT, SHEN B, LAU CW, TIAN XY, TSANG SY, YAO X, CHEN ZY, HUANG Y: 4-aminopyridine-sensitive $\mathrm{K}^{+}$channels contribute to NaHS-induced membrane hyperpolarization and relaxation in the rat coronary artery. Vasc Pharmacol 53: 94-98, 2010.

CHEN L, INGRID S, DING YG, LIU Y, OI JG, TANG CS, DU JB: Imbalance of endogenous homocysteine and hydrogen sulfide metabolic pathway in essential hypertensive children. Chin Med J (Engl) 120: 389-393, 2007.

CHENG Y, NDISANG JF, TANG G, CAO K, WANG R: Hydrogen sulfide-induced relaxation of resistance mesenteric artery beds of rats. Am J Physiol Heart Circ Physiol 287: H2316-H2323, 2004.

COLETTA C, PAPAPETROPOUlOS A, ERDElyi K, OlAH G, MÓdis $\mathrm{K}$, PANOPOUlos $\mathrm{P}$, ASIMAKOPOULOU A, GERÖ D, SHARINA I, MARTIN E, SZABO C: Hydrogen sulfide and nitric oxide are mutually dependent in the regulation of angiogenesis and endothelium-dependent vasorelaxation. Proc Natl Acad Sci USA 109: 9161-9166, 2012.

CORTESE-KROTT MM, FERNANDEZ BO, SANTOS JL, MERGIA E, GRMAN M, NAGY P, KELM M, BUTLER A, FEELISCH M: Nitrosopersulfide ( $\mathrm{SSNO}^{-}$) accounts for sustained $\mathrm{NO}$ bioactivity of S-nitrosothiols following reaction with sulfide. Redox Biol 2: 234-244, 2014.

CORTESE-KROTT MM, KUHNLE GG, DYSON A, FERNANDEZ BO, GRMAN M, DUMOND JF, BAROWW MP, MCLEOD G, NAKAGAWA H, ONDRIAS K, NAGY P, KING SB, SAAVEDRA JE, KEEFER LK, SINGER M, KELM M, BUTLER AR, FEELISCH M: Key bioactive reaction products of the $\mathrm{NO} / \mathrm{H}_{2} \mathrm{~S}$ interaction are S/N-hybrid species, polysulfides, and nitroxyl. Proc Natl Acad Sci USA 112: E4651-E4660, 2015.

DAS UN: Essential fatty acids: biochemistry, physiology and pathology. Biotechnol J 1: 420-439, 2006.

DOELLER JE, ISBELL TS, BENAVIDES G, KOENITZER J, PATEL H, PATEL RP, LANCASTER JR, DARLEYUSMAR VM, KRAUS DW: Polarographic measurement of hydrogen sulfide production and consumption by mammalian tissues. Anal Biochem 341: 40-51, 2005. 
DROBNA M, MISIAK A, HOLLAND T, KRISTEK F, GRMAN M, TOMASOVA M, BERENYIOVA A, CACANYIOVA S, ONDRIAS K: Captopril partially decreases the effect of $\mathrm{H}_{2} \mathrm{~S}$ on rat blood pressure and inhibits $\mathrm{H}_{2} \mathrm{~S}$-induced nitric oxide release from S-nitrosoglutathione. Physiol Res 64: 479-486, 2015.

DURANTE W, JOHNSON FK, JOHNSON RA: Role of carbon monoxide in cardiovascular funcion. J Cell Mol Med 10: 672-686, 2006.

FILIPOVIC MR, MILJKOVIC J, NAUSER T, ROYZEN M, KLOS K, SHUBINA T, KOPPENOL WH, LIPPARD SJ, IVANOVIC-BURMAZOVIC I: Chemical characterization of the smallest S-nitrosothiol, HSNO; cellular cross-talk of $\mathrm{H}_{2} \mathrm{~S}$ and S-nitrosothiols. J Am Chem Soc 134: 12016-12027, 2012.

FURCHGOTT RF, ZAWADZKI JV: The obligatory role of endothelial cells in the relaxation of arterial smooth muscle by acetylcholine. Nature 288: 373-376, 1980.

FURNE J, SPRINGFIELD J, KOENIG T, DEMASTER E, LEVITT MD: Oxidation of hydrogen sulfide and methanethiol to thiosulfate by rat tissues: a specialized function of the colonic mucosa. Biochem Pharmacol 62: 255-259, 2001.

FURNE J, SAEED A, LEVITT MD: Whole tissue hydrogen sulfide concentrations are orders of magnitude lower than presently accepted values. Am J Physiol Regul Integr Comp Physiol 295: R1479-R1485, 2008.

GAO L, WANG W, LI YL, SCHULTZ HD, LIU D, CORNISH KG, ZUCKER IH: Sympathoexcitation by central ANG II: Roles for $\mathrm{AT}_{1}$ receptor upregulation and $\mathrm{NAD}(\mathrm{P}) \mathrm{H}$ oxidase in RVLM. Am J Physiol Heart Circ Physiol 288: H2271-H2279, 2005.

GARDINER SM, MARCH JE, KEMP PA, BENETT T: Bolus injection of human UII in conscious rats evokes a biphasic haemodynamic response. Br J Pharmacol 143: 422-430, 2004.

GENG B, YANG J, QI Y, ZHAO J, PANG Y, DU J, TANG C: $\mathrm{H}_{2} \mathrm{~S}$ generated by heart in rat and its effects on cardiac function. Biochem Biophys Res Commun 313: 362-368, 2004.

GENG B, CUI Y, ZHAO J, YU F, ZHU Y, XU G, ZHANG Z, TANG C, DU J: Hydrogen sulfide downregulates the aortic L-arginine/nitric oxide pathway in rats. Am J Physiol Regul Integr Comp Physiol 293: R1608-R1618, 2007.

GEROVÁ M, MESAROŠ S, KITTOVÁ M, HATRIK S, KRISTEK F, MALINSKI T: Nitric oxide in the periendothelial area of femoral vein of the dog assessed in vivo by a porphyrinic sensor. Physiol Res 45 : 285-289, 1996.

GINES FF, VINCENTE KE, RICCA R: Right ventricle systolic pressure increase following intravenous acetylcholine injection. Acta Physiol Pharmacol Ther Latinoam 44: 77-84, 1994.

GREINER R, PÁLINKÁS Z, BÄSELL K, BECHER D, ANTELMANN H, NAGY P, DICK TP: Polysulfides link H2 to protein thiol oxidation. Antioxid Redox Signal 19: 1749-1765, 2013.

GRMAN M, MISAK A, JACOB C, TOMASKOVA Z, BERTOVA A, BURKHOLZ T, DOCOLOMANSKY P, HABALA L, ONDRIAS K: Low molecular thiols, $\mathrm{pH}$ and $\mathrm{O}_{2}$ modulate $\mathrm{H}_{2} \mathrm{~S}$-induced S-nitrosoglutathione decomposition - •NO release. Gen Physiol Biophys 32: 429-444, 2013.

HOSOKI R, MATSUKI N, KIMURA H: The possible role of hydrogen sulfide as an endogenous smooth muscle relaxant in synergy with nitric oxide. Biochem Biophys Res Commun 237: 527-531, 1997.

ISHIGAMI M, HIRAKI K, UMEMURA K, OGASAWARA Y, ISHII K, KIMURA H: Hydrogen sulfide and a mechanism of its release in the brain. Antioxid Redox Signal 11: 205-214, 2009.

JACKSON-WEAVER O, OSMOND JM, RIDDLE MA, NAIK JS, GONZALEZ BOSC LV, WALKER BR, KANAGY $\mathrm{NL}$ : Hydrogen sulfide dilates rat mesenteric arteries by activating endothelial large-conductance $\mathrm{Ca}^{2+}$-activated $\mathrm{K}^{+}$channels and smooth muscle $\mathrm{Ca}^{2+}$ sparks. Am J Physiol Heart Circ Physiol 304: H1446-H1454, 2013.

KIMURA H: Hydrogen sulfide: its production, release and functions. Amino Acids 43: 113-121, 2010.

KIMURA H: Hydrogen sulfide and polysulfides as biological mediators, Molecules 19: 16146-16157, 2015.

KING AJ, PFEFFER JM, PFEFFER MA, BRENNER BM: Systemic hemodynamic effects of endothelin in rats. Am J Physiol 258: H787-H792, 1990.

KUBO S, DOE I, KUROKAWA Y, NISHIKAWA H, KAWABATA A: Direct inhibition of endothelial nitric oxide synthase by hydrogen sulfide: contribution to dual modulation of vascular tension. Toxicology 232: 138-146, 2007. 
LAGGNER H, HERMANN M, ESTERBAUER H, MUELLNER MK, EXNER M, GMEINER BM, KAPIOTIS S: The novel gaseous vasorelaxant hydrogen sulfide inhibits angiotensin-converting enzyme activity of endothelial cells. J Hypertens 25: 2100-2104, 2007.

LEE SW, CHENG Y, MOORE PK, BIAN JS: Hydrogen sulphide regulates intracellular pH in vascular smooth muscle cells. Biochem Biophys Res Commun 358: 1142-1147, 2007.

LEVITT MD, ABDEL-REHIM MS, FURNE J: Free and acid labile hydrogen sulfide concentrations in mouse tissues: anomalously high free hydrogen sulfide in aortic tissue. Antioxid Redox Signal 15: 373-378, 2011.

LI L, WHITEMAN M, GUAN YY, NEO KL, CHENG Y, LEE SW, ZHAO Y, BASKAR R, TAN CH, MOORE PK: Characterization of a novel, water-soluble hydrogen sulfide-releasing molecule (GYY4137): new insights into the biology of hydrogen sulfide. Circulation 117: 2351-2360, 2008.

LI S, PING NN, CAO L, MI YN, CAO YX: $\mathrm{H}_{2} \mathrm{~S}$ induces vasoconstriction of rat cerebral arteries via cAMP/adenylyl cyclase pathway Toxicol Appl Pharmacol 289: 389-396, 2015.

LIM JJ, LIU YH, KHIN ES, BIAN JS: Vasoconstrictive effect of hydrogen sulfide involves downregulation of cAMP in vascular smooth muscle cells. Am J Physiol Cell Physiol 295: C1261-C1270, 2008.

LIU YH, BIAN JS: Bicarbonate-dependent effect of hydrogen sulfide on vascular contractility in rat aortic rings. $A m J$ Physiol Cell Physiol 299: C866-C872, 2010.

LIU YH, LU M, HU LF, WONG PT, WEBB DG, BIAN JS: Hydrogen sulphide in the mammalian cardiovascular system. Antioxid Redox Signal 17: 141-185, 2012.

LU M, LIU YH, GOH HS, WANG JJ, YONG QC, WANG R, BIAN JS: Hydrogen sulfide inhibits plasma renin activity. J Am Soc Nephrol 21: 993-1002, 2010.

LU M, LIU YH, HO CY, TIONG CX, BIAN JS: Hydrogen sulfide regulates cAMP homeostasis and renin degranulation in As4.1 and rat renin-rich kidney cells. Am J Physiol Cell Physiol 302: C59-C66, 2012.

LYKAKIS YN, FERRERI C, CHATGILIALOGLU C: The sulfhydryl radical (HS ${ }^{*} \mathrm{HS}^{*}{ }^{\circ}$ ): a contender for the isomerization of double bonds in membrane lipids. Angew Chem 119: 1946-1948, 2007.

MA S, ZHU XY, EIRIN A, WOOLLARD JR, JORDAN KL, TANG H, LERMAN A, LERMAN LO: Perirenal fat promotes renal arterial endothelial dysfunction in obese swine through tumor necrosis factor- $\alpha$. J Urol 195 : 1152-1159, 2016.

MALEKOVA L, KRIZANOVA O, ONDRIAS K: $\mathrm{H}_{2} \mathrm{~S}$ and $\mathrm{HS}^{-}$donor NaHS inhibits intracellular chloride channels. Gen Physiol Biophys 28: 190-194, 2009.

MARKS GS, BRIEN JF, NAKATSU K, MCLAUGHLIN BE: Does carbon monoxide have a physiological function? Trends Pharmacol Sci 12: 185-188, 1991.

MIERSCH S, MUTUS B: Protein S-nitrosation: Biochemistry and characterization of protein thiol-NO interactions as cellular signaling. Clin Biochem 38: 777-791, 2005.

MUELLNER MK, SCHREIER SM, LAGGER M, HERMANN H, ESTERBAUER H, EXNER BM, GMEINER BM, KAPIOTIS S: Hydrogen sulfide destroys lipid hydoperoxides in oxidized LDL. Biochem J 420: 277-281, 2009.

MUSTAFA AK, SIKKA G, GAZI SK, STEPPAN J, JUNG SM, BHUNIA AK, BARODKA VM, GAZI FK, BARROW RK, WANG R, AMZEL LM, BERKOWITZ DE, SNYDER SH: Hydrogen sulfide as endotheliumderived hyperpolarizing factor sulfhydrates potassium channels. Circ Res 109: 1259-1268, 2011.

NG ES, CHENG ZJ, ELLIS A, DING H, JIANG Y, LI Y, HOLLENBERG MD, TRIGGLE CR: Nitrosothiol stores in vascular tissue: modulation by ultraviolet light, acetylcholine and ionomycin. Eur J Pharmacol 560: 183-192, 2007.

ONDRIAS K, STASKO A, CACANYIOVA S, SULOVA Z, KRIZANOVA O, KRISTEK F, MALEKOVA L, KNEZL V, BEIER A: $\mathrm{H}_{2} \mathrm{~S}$ and HS-donor NaHS releases nitric oxide from nitrosothiols, metal nitrosyl complex, brain homogenate and murine L1210 leukaemia cells. Pflugers Arch 457: 271-279, 2008.

PALMER RM, FERRIGE AG, MONCADA S: Nitric oxide release accounts for the biological activity of endotheliumderived relaxing factor. Nature 327: 524-526, 1987.

PEERS C, BAUER CC, BOYLE JP, SCRAGG JL, DALLAS ML: Modulation of ion channels by hydrogen sulfide. Antioxid Redox Signal 17: 95-105, 2012.

PECHÁŇOVÁ O: Contribution of captopril thiol group to the prevention of spontaneous hypertension. Physiol Res $\mathbf{5 6}$ (Suppl 2): S41-S48, 2007. 
PING NN, LI S, MI YN, CAO L, CAO YX: Hydrogen sulphide induces vasoconstriction of rat coronary artery via activation of $\mathrm{Ca}^{2+}$ influx. Acta Physiol 214: 88-96, 2015.

RAM CV: Renovascular hypertension. Cardiol Clin 6: 483-508, 1988.

RICHARDSON CJ, MAGEE EA, CUMMINGS JH: A new method for the determination of sulphide in gastrointestinal contents and whole blood by microdistillation and ion chromatography. Clin Chim Acta 293: 115-125, 2000.

SHI YX, CHEN Y, ZHU YZ, HUANG GY, MOORE PK, HUANG SH, YAO T, ZHU YC: Chronic sodium hydrosulfide treatment decreases medial thickening of intramyocardial coronary arterioles, interstitial fibrosis, and ROS production in spontaneously hypertensive rats. Am J Physiol Heart Circ Physiol 293: H2093-H2100, 2007.

SHIBUYA N, MIKAMI Y, KIMURA Y, NAGAHARA N, KIMURA H: Vascular endothelium expresses 3-mercaptopyruvate sulfurtransferase and produces hydrogen sulfide. J Biochem 146: 623-626, 2009.

SCHLEIFENBAUM J, KOHN C, VOBLOVA N, DUBROVSKA G, ZAVARIRSKAYA O, GLOE T, CREAN CS, LUFT FC, HUANG Y, SCHUBERT R, GOLLASCH M: Systemic peripheral artery relaxation by KCNQ channel openers and hydrogen sulfide. J Hypertens 28: 1875-1882, 2010.

STAMLER JS, LAMAS S, FANG FC: Nitrosylation: The prototypic redox-based signaling mechanism. Cell 106: 675-683, 2001.

STASKO A, BREZOVA M, ZALIBERA M, BISKUPIC S, ONDRIAS K: Electron transfer - a primary step in the in the reactions of sodium hydrogen sulfide, an $\mathrm{H}_{2} \mathrm{~S} / \mathrm{HS}^{-}$donor. Free Radic Res 43: 581-593, 2009.

TANG G, WU L, LIANG W, WANG R: Direct stimulation of $\mathrm{K}_{\mathrm{ATP}}$ channels by exogenous and endogenous hydrogen sulfide in vascular smooth muscle cells. Mol Pharmacol 68: 1757-1764, 2005.

TOMASKOVA Z, CACANYIOVA S, BENCO A, KRISTEK F, DUGOVICOVA L, HRBAC J, ONDRIAS K: Lipids modulate $\mathrm{H}_{2} \mathrm{~S} / \mathrm{HS}$-induced NO release from S-nitrosoglutathione. Biochem Biophys Res Commun 390: 1241$1244,2009$.

TOMASOVA L, PAVLOVICOVA M, MALEKOVA L, MISAK A, KRISTEK F, GRMAN M, CACANYIOVA S, TOMASEK M, TOMASKOVA Z, PERRY A, WOOD ME, LACINOVA L, ONDRIAS K, WHITEMAN M: Effects of AP39, a novel triphenylphosphonium derivatised anethole dithiolethione hydrogen sulfide donor, on rat haemodynamic parameters and chloride and calcium Cav3 and RyR2 channels. Nitric Oxide 46: 131-144, 2015.

WANG R: Two's company, three's a crowd: can $\mathrm{H}_{2} \mathrm{~S}$ be the third endogenous gaseous transmitter? FASEB J 16: $1792-$ 1798, 2002.

WANG R: Physiological implications of hydrogen sulfide: a whiff exploration that blossomed. Physiol Rev 92: 791$896,2012$.

WHITEMAN M, GOODING KM, WHATMORE JL, BALL CI, MAWSON D, SKINNER K, TOOKE JE, SHORE AC: Adiposity is a major determinant of plasma levels of the novel vasodilator hydrogen sulphide. Diabetologia 53: 1722-1726, 2010.

WHITFIELD NL, KREIMIER EL, VERDIAL FC, SKOVGAARD N, OLSON KR: Reappraisal of $\mathrm{H}_{2} \mathrm{~S} / \mathrm{sulfide}$ concentration in vertebrate blood and its potential significance in ischemic preconditioning and vascular signaling. Am J Physiol Regul Integr Comp Physiol 294: R1930-R1937, 2008.

WU CC, YEN MH: Higher level of plasma nitric oxide in spontaneously hypertensive rats. Am J Hypertens 12: $476-$ $482,1999$.

XIA M, CHEN L, MUH RW, LI PL, LI N: Production and actions of hydrogen sulfide, a novel gaseous bioactive substance, in the kidneys. J Pharmacol Exp Ther 329: 1056-1062, 2009.

YAN H, DU J, TANG C: The possible role of hydrogen sulfide on the pathogenesis of spontaneous hypertension in rats. Biochem Biophys Res Commun 313: 22-27, 2004.

YANG G, WU L, JIANG B, YANG W, QI J, CAO K, MENG Q, MUSTAFA AK, MU W, ZHANG S, SNYDER SH, WANG R: $\mathrm{H}_{2} \mathrm{~S}$ as a physiologic vasorelaxant: hypertension in mice with deletion of cystathionine gammalyase. Science 322: 587-590, 2008.

YONG QC, CHOO CH, TAN BH, LOW CM, BIAN JS: Effect of hydrogen sulfide on intracellular calcium homeostasis in neuronal cells. Neurochem Int 56: 508-515, 2010.

ZHANG Y, HOGG N: S-Nitrosothiols: cellular formation and transport. Free Radic Biol Med 38: 831-838, 2005. 
ZHAO W, WANG R: $\mathrm{H}_{2} \mathrm{~S}$-induced vasorelaxation and underlying cellular and molecular mechanisms. Am J Physiol Heart Circ Physiol 283: H474-H480, 2002.

ZHAO W, ZHANG J, LU Y, WANG R: The vasorelaxant effect of $\mathrm{H}_{2} \mathrm{~S}$ as a novel endogenous gaseous $\mathrm{K}_{\mathrm{ATP}}$ channel opener. EMBO J 20: 6008-6016, 2001.

ZHAO W, NDISANG JF, WANG R: Modulation of endogenous production of $\mathrm{H}_{2} \mathrm{~S}$ in rat tissues. Can $J$ Physiol Pharmacol 81: 848-853, 2003.

ZHAO X, ZHANG LK, ZHANG CY, ZENG XJ, YAN H, JIN HF, TANG CS, DU JB: Regulatory effect of hydrogen sulfide on vascular collagen content in spontaneously hypertensive rats. Hypertens Res 31: 1619-1630, 2008.

ZHAO Y, VANHOUTTE PM, LEUNG SWS: Endothelial nitric oxide synthase-independent release of nitric oxide in the aorta of the spontaneously hypertensive rat. J Pharmacol Exp Ther 344: 15-22, 2012. 